\title{
Correlation of Glycemic and Lipid Control Parameters with Cognitive Dysfunction Scores, in Type 2 Diabetic Persons
}

\author{
Results from a cross- sectional study
}

\begin{abstract}
GINA BOTNARIU ${ }^{1,2}$, ALINA POPA ${ }^{1,2, *}$, GETA MITREA $^{3}$, MARIUS MANOLE $^{4 *}$, MARIANA PACURAR $^{5}$, MARIANA ANGHELE ${ }^{3}$, CECILIA CURIS ${ }^{3}$, ELINA TEODORESCU ${ }^{6}$

${ }^{1}$ Grigore T. Popa University of Medicine and Pharmacy, 16 Universitatii Str., 700115, Iasi, Romania

${ }^{2}$ Clinical Department of Diabetes, Nutrition and Metabolic Disease, Universitary Hospital St. Spiridon, 1 Independentei Blvd., 700111, lasi, Romania

3Dunarea de J os University, Faculty of Medicine, 47 Domneasca Str., 800008,Galati, Romania

${ }^{4}$ University of Medicine and Pharmacy luliu Hatieganu, Faculty of Dental Medicine, 8 Victor Babes Str.,400012, Cluj Napoca, Romania

5University of Medicine and Pharmacy Tg. Mures, Faculty of Dental Medecine. 38 Gheorghe Marinescu Str., 540142,Tg.Mures, Romania

UUniversity of Medicine and Pharmacy Carol Davila, Orthodontic Department, 8 Eroii Sanitari Blvd, 050474, Bucharest, Romania

Diabetes-related cognitive dysfunction is considered a long-term complication of diabetes. In this crosssectional study was studied the relationship between cognitive dysfunction (assessed by using two standardized questionnaires), lipid profile parameters and fatty free acids intake, in outpatients, hospitalized for their periodical control. The Mini-Mental State Exam (MMSE) and The Montreal Cognitive Assessment (MoCA) score were related to the body mass index (BMI), high density cholesterol (HDLC), glycated hemoglobin ( $\mathrm{Hb}$ Alc) and intake of choline and eicosapentaenoic acid (all Ps $<.05$, excepting the relationship between $M M S E$ and $H D L_{c}$ ). The implications of FFA intake in dementia development, in type 2 diabetics, is important for disease management and prevention .
\end{abstract}

Keywords: The Mini-Mental State Exam (MMSE), The Montreal Cognitive Assessment (MoCA) body mass index (BMI), high density cholesterol (HDLC), glycated hemoglobin (Hb Alc), Type 2 Diabetes

Diabetes-related cognitive dysfunction may be viewed as another long-term complication of diabetes [1]. It is associated with mental and motor slowing and decrements of attention and executive functioning. Subcortical smallvessel disease (SSVD) is described from clinical, imaging and neuropathological view points. SSVD is considered the most prevalent ischemic brain disorder. It's frequency increases with age [2].

Vascular risk factors include hypertension, diabetes, hyperlipidemia, elevated homocysteine, and obstructive sleep apnea. Ischemic white matter lesions are the hallmark of SSVD $[3,4]$. Cognitive impairement in type 2 diabetes is characterised by neural slowing, increased cortical atrophy, microstructural abnormalities in white matter tracts and changes in concentrations of brain neurometabolites $[5,6]$. Hypoglycemic crises and also long-term hyperglycemia leads to white matter (WM) impairment [7] and brain dysfunction [8].

In this observational study was studied the relationship between cognitive dysfunction (assessed by two standardized questionnaires) and lipide profile parameters in outpatients patients, hospitalised for their periodical control. The intake of lipids was evaluated by using 24 hours dietary recall (24HR) and related to serum lipids and cognitive scores. Finding a relationships would be useful to identify an algorithm for clinical practice, in disease prevention.

\section{Experimental part}

Materials and methods

We conducted a cross-sectional study in a sample of 138 type 2 diabetic patients, hospitalised for their annual control, during 2017. We created a pro forma for data collection that was completed during hospitalisation. We collected:
-Demographic data: age, gender, area of residence (urban or rural), family status (married or single,) and duration of formal education;

-The duration of diabetes, presence of chronic complications, type of treatment (insulin or oral agents);

-Anthropometric parameters: body mass index (BMI) and waist circumference;

-Laboratory findings: glycated hemoglobine ( $\mathrm{Hb} \mathrm{AlC}$ ), cholesterol, high density cholesterol (HDLC), low density cholesterol (LDLC), triglycerides;

-Diet evaluation $-24 \mathrm{~h}$ dietary recall (24-HR).

The Mini-Mental State Exam (MMSE) is a widely used test of cognitive function among the elderly; it includes tests of orientation, attention, memory, language and visual-spatial skills. Any subject with MMSE at or above 26 may be presumed competent unless listed otherwise at last evaluation.

The Montreal Cognitive Assessment (MoCA) is a widely used to detect cognitive impairment [9]. It was validated in the setting of mild cognitive impairment, and has subsequently been adopted in numerous other settings clinically. MoCA scores range between 0 and 30 . A score of 26 or over is considered to be normal [10].

The data were included in a database using Microsoft Office Excel 2007. For statistical analysis we used SPSS programme (Statistical Package for Social Sciences) version 13.0 for Windows (Chicago, IL, USA). The Kolmogorov test was used to evaluate the normal distribution of the analyzed data. To assess the association between variables Spearman correlation coefficients were determined. ANOVA test (the distribution of the data was normal) was used to calculate if there were significant differences between the values of repeated measurements.

*email: roxyal04@gmail.com, Phone:+40752064474; mnole22@yahoo.com; Phone: +40752064474 


\section{Results and discussions}

The participants were selected from type 2 diabetes outpatients of the Diabetes Centre in lasi hospitalised for their annual control, in 2017. The main part of the patients were males (61.34\%) and came from the urban environement (57.98\%). An important proportion of them were overweight (27.3\%) and obese (53.4\%) and had a poor glycemic control (57.7\%). The prevalence of mild cognitive impairment estimated by Mini-Mental State Exam (MMSE) was 19.7\%. Using Montreal Cognitive Assessment (MoCA) the prevalence of the cognitive imairement was higher (37\%).

The intake of essential fatty acids - eicosapentaenoic acid (EPA) and docosahexaenoic acid (DHA) and choline were estimated by using $24 \mathrm{HR}$ questionnaire. Dietary

\begin{tabular}{|l|l|l|l|l|}
\hline & Minimum & Maximum & Mean & Std. Deviation \\
\hline Age & 20 & 66 & 54.92 & 8.92 \\
\hline Waist circumference & 66 & 135 & 96.93 & 15.60 \\
\hline Cholesterol & 86 & 333 & 184.21 & 46.94 \\
\hline HDL & 10 & 89 & 41.31 & 18.74 \\
\hline Trigliceride & 43 & 617 & 179.76 & 137.77 \\
\hline HbA1c & 5 & 14 & 7.88 & 1.86 \\
\hline MMSE score & 23 & 31 & 26.21 & 2.07 \\
\hline MoCA score & 22 & 37 & 28.07 & 5.25 \\
\hline Choline mg & 103 & 682 & 305.90 & 196.21 \\
\hline EPA g & 0.00 & 0.67 & 0.17 & 0.19 \\
\hline DHA g & 0.00 & 0.89 & 0.19 & 0.25 \\
\hline BMI & 6.42 & 44.20 & 29.99 & 6.37 \\
\hline
\end{tabular}

\begin{tabular}{|l|l|l|l|}
\hline \multirow{2}{*}{ Waist circumference } & & MMSE score & MOCA score \\
\hline \multirow{2}{*}{ BMI } & Correlation Coefficient & -.039 & -.029 \\
\cline { 2 - 4 } & Sig. (2-tailed) & .553 & .654 \\
\hline \multirow{2}{*}{ Cholesterol } & Correlation Coefficient & $-.134^{\circ}$ & $-.152^{\circ}$ \\
\cline { 2 - 4 } & Sig. (2-tailed) & .039 & .019 \\
\hline \multirow{2}{*}{ HDL } & Correlation Coefficient & .026 & .040 \\
\cline { 2 - 4 } & Sig. (2-tailed) & .711 & .577 \\
\hline \multirow{2}{*}{ Trigliceride } & Correlation Coefficient & $.373^{\circ}$ & .080 \\
\cline { 2 - 4 } & Sig. (2-tailed) & .000 & .412 \\
\hline \multirow{3}{*}{ HbA1c } & Correlation Coefficient & .111 & .105 \\
\cline { 2 - 4 } & Sig. (2-tailed) & .199 & .224 \\
\hline \multirow{2}{*}{ Coline (mg) } & Correlation Coefficient & $.177^{\circ}$ & .205 \\
\cline { 2 - 4 } & Sig. (2-tailed) & .027 & .010 \\
\hline \multirow{2}{*}{ EPA (g) } & Correlation Coefficient & $.346^{\circ}$ & $.519^{\circ}$ \\
\cline { 2 - 4 } & Sig. (2-tailed) & .000 & .000 \\
\hline \multirow{2}{*}{ DHA (g) } & Correlation Coefficient & $.236^{\circ}$ & $.269^{\circ}$ \\
\cline { 2 - 4 } & Sig. (2-tailed) & .018 & .007 \\
\cline { 2 - 4 } & Correlation Coefficient & .185 & .174 \\
\cline { 2 - 4 } & Sig. (2-tailed) & .067 & .086 \\
\hline
\end{tabular}

\begin{tabular}{|c|c|c|c|c|c|c|}
\hline & \multirow[t]{2}{*}{ Mean } & \multirow[t]{2}{*}{ Std. Deviation } & \multicolumn{2}{|c|}{$95 \%$ Confidence Interval for Mean } & \multirow[t]{2}{*}{$\mathrm{p}$} \\
\hline & & & & Lower Bound & Upper Bound & \\
\hline \multirow[t]{2}{*}{ IMC } & normal score & 29.75 & 6.58 & 28.81 & 30.69 & \multirow[t]{2}{*}{.24} \\
\hline & low score & 30.97 & 5.44 & 29.37 & 32.57 & \\
\hline \multirow[t]{2}{*}{$\mathrm{CA}$} & normal score & 96.55 & 15.85 & 94.29 & 98.82 & \multirow[t]{2}{*}{.45} \\
\hline & low score & 98.47 & 14.60 & 94.18 & 102.75 & \\
\hline \multirow[t]{2}{*}{ Cholesterol } & normal score & 187.55 & 46.63 & 180.29 & 194.81 & \multirow[t]{2}{*}{.38} \\
\hline & low score & 170.03 & 46.17 & 154.85 & 185.21 & \\
\hline \multirow[t]{2}{*}{ HDL } & normal score & 43.06 & 19.07 & 39.06 & 47.05 & \multirow[t]{2}{*}{.026} \\
\hline & low score & 32.06 & 14.01 & 24.86 & 39.26 & \\
\hline \multirow[t]{2}{*}{ Trigliceride } & normal score & 186.51 & 145.15 & 159.08 & 213.94 & \multirow[t]{2}{*}{.23} \\
\hline & low score & 150.04 & 95.72 & 110.52 & 189.56 & \\
\hline \multirow[t]{2}{*}{ HbAlc } & normal score & 7.98 & 1.95 & 7.63 & 8.33 & \multirow[t]{2}{*}{.17} \\
\hline & low score & 7.48 & 1.46 & 6.97 & 8.00 & \\
\hline \multirow[t]{2}{*}{ Choline (mg) } & normal score & 326.91 & 194.69 & 299.12 & 354.70 & \multirow[t]{2}{*}{.001} \\
\hline & low score & 220.51 & 180.28 & 167.57 & 273.44 & \\
\hline \multirow[t]{2}{*}{ EPA (g) } & normal score & .17 & .19 & .13 & .21 & \multirow[t]{2}{*}{.046} \\
\hline & low score & .15 & .21 & .06 & .26 & \\
\hline \multirow[t]{2}{*}{ DHA (g) } & normal score & .20 & .24 & .14 & .25 & \multirow[t]{2}{*}{.3} \\
\hline & low score & .17 & .28 & .04 & .30 & \\
\hline
\end{tabular}

recommended intake (DRI) for choline is $400 \mathrm{mg} /$ day and DRI for EPA and DHA is $500 \mathrm{mg} /$ day according to European Food Safety Authority. A lower mean intake of these nutrients then recommended were noticed in this sample (table 1).

MMSE score and MoCA were related to the BMI, HDL cholesterol, $\mathrm{Hb}$ Alc and the intake of choline and EPA (all $P S<.05$, excepting the relation between MMSE and HDL) (table 2).

The diabetics with mild cognitive impairement had a lower daily intake of choline and eicosapentaenoic acid than patients which obtained a normal score at MMSE $(p=0.001$ and 0.046 , respectively). A lower concentration of HDLc was noticed in patients with an abnormal MMSE score $(p=0.026)$. The patients with cognitive disfunction had a higher BMI and waist circumference and a higher intake of docosahexaenoic acid (not significant reationships) (table 3).
Table 1

DESCRIPTIVE CHARACTERISTICSOF THE PATIENTS
Table 2

RELATIONSHIP BETWEEN COGNITIVE ASSESSMENT SCORES, LIPID PROFILE AND ESSENTIAL FATTY ACIDS INTAKE
MILDCOGNITIVE IMPAIRMENT

(MMSE) ACCORDING TO

CLINICAL ANDBIOCHEMICAL EVALUATION 


\begin{tabular}{|c|c|c|c|c|c|c|}
\hline & \multirow[t]{2}{*}{ Mean } & \multirow[t]{2}{*}{ Std. Deviation } & \multicolumn{2}{|c|}{$95 \%$ Confidence Interval for Mean } & \multirow[t]{2}{*}{$\mathrm{p}$} \\
\hline & & & & Lower Bound & Upper Bound & \\
\hline \multirow[t]{2}{*}{ BMI } & normal score & 29.08 & 6.70 & 28.00 & 30.17 & \multirow[t]{2}{*}{.004} \\
\hline & low score & 31.53 & 5.49 & 30.37 & 32.69 & \\
\hline \multirow[t]{2}{*}{ WC } & normal score & 97.18 & 15.81 & 94.63 & 99.73 & \multirow[t]{2}{*}{.75} \\
\hline & low score & 96.51 & 15.30 & 93.27 & 99.75 & \\
\hline \multirow[t]{2}{*}{ cholesterol } & normal score & 183.58 & 45.05 & 175.77 & 191.40 & \multirow[t]{2}{*}{.79} \\
\hline & low score & 185.38 & 50.63 & 173.21 & 197.54 & \\
\hline \multirow[t]{2}{*}{ HDL } & normal score & 41.36 & 18.25 & 36.69 & 46.04 & \multirow[t]{2}{*}{97} \\
\hline & low score & 41.24 & 19.59 & 35.42 & 47.06 & \\
\hline \multirow[t]{2}{*}{ Trigliceride } & normal score & 191.22 & 149.82 & 160.70 & 221.74 & \multirow[t]{2}{*}{.13} \\
\hline & low score & 152.53 & 100.15 & 120.49 & 184.56 & \\
\hline \multirow[t]{2}{*}{ HbAlc } & normal score & 8.30 & 1.96 & 7.89 & 8.71 & \multirow[t]{2}{*}{.001} \\
\hline & low score & 7.29 & 1.54 & 6.91 & 7.68 & \\
\hline \multirow[t]{2}{*}{ Choline (mg) } & normal score & $37 \sqrt{3.48}$ & 188.93 & 343.00 & 403.96 & \multirow[t]{2}{*}{.001} \\
\hline & low score & 190.69 & 149.80 & 158.95 & 222.43 & \\
\hline \multirow[t]{2}{*}{ EPA (g) } & normal score & .20 & .20 & .15 & .25 & \multirow[t]{2}{*}{.028} \\
\hline & low score & .11 & .17 & .06 & .17 & \\
\hline \multirow[t]{2}{*}{ DHA (g) } & normal score & .24 & .26 & .17 & .31 & \multirow[t]{2}{*}{.023} \\
\hline & low score & .12 & .21 & .05 & .19 & \\
\hline
\end{tabular}

Table 4

MILDCOGNITIVE IMPAIRMENT (MOCA) AND SAMPLE CHARACTERISTICS
Using MoCA evaluation, mild cognitive impairement was associated with BMI $(p=.004)$, glicemic control $(p=.001)$, choline intake $(p=.001)$ and essential fatty acids ( DHA $p=0.28$; $E P A-p=0,23$ ). Lipid profile wasn't related with the cognitive impairement in this sample (table 4).

In this sample, the prevalence of mild cognitive impairment estimated by Mini-Mental State Exam (MMSE) was $19.7 \%$. Using Montreal Cognitive Assessment (MoCA) the prevalence of the cognitive impairement was higher (37\%). The Rotterdam study of over 6000 patients with type 2 diabetes showed a 2-fold increase in the risk for dementia [11].

In our study, cognitive dysfunction scores were related to the BMI, HDL cholesterol, $\mathrm{Hb}$ Alc, choline intake and EPA. The patients with cognitive dysfunction had a higher $\mathrm{BMI}$ and waist circumference. Hyperglycemia leads to increases in diacylglycerol and protein kinase C (PKC), which decreases the levels of endothelial nitric oxide synthase (eNOS) and thus lowers the bioavailability of nitric oxide (NO), leading to impaired vasorelaxation. PKC leads to the proliferation and migration of vascular smooth muscle cells (VSMCS), an important step in the development of atherosclerosis [12]. Studies have shown that patients with a $\mathrm{HbA}_{1 \mathrm{c}}$ of greater than $7 \%$ have a 4 -fold increase in the development of mild cognitive impairment [13].

In many studies, the cognitive domains that were associated with impairment covered a wide range of abilities: processing speed, nonverbal memory, executive function (Edinburgh Type 2 Diabetes Study), psychomotor speed memory, verbal learning, executive function (Atherosclerosis Risk in Communities Study (ARIC), Action to Control Cardiovascular Risk in Diabetes-Memory in Diabetes (ACCORD-MIND) [12]. Cerebral microvascular disease may play a role in acceleration of cognitive decline in diabetes. The Edinburgh Type 2 Diabetes Study showed that microvascular disease is associated with cognitive decline in diabetes [14]. The severity of diabetic retinopathy was related to cognitive domains of verbal fluency, information processing speed and mental flexibility [14].

In our study, a lower concentration of HDL was noticed in patients with an abnormal MMSE score. Sun Y and all [15] showed that a higher serum concentration of highdensity lipoprotein cholesterol ( $\mathrm{HDL}_{c}$ ) was associated with a better executive performance. Multilevel modeling showed that highest tertile of $\mathrm{HDL}_{\mathrm{c}}$ was associated with better executive function.

HDL undergoes significant qualitative changes, both in structure and function, in diabetics [16] and has multiple important functions in brain. HDL dysfunction in central nervous system may directly induce cognitive impairment [17]. Some small particles of HDL e.g. apolipoprotein A-1 may cross the blood-brain barrier. The anti-oxidant and antiinflammatory properties of apoA-l/HDL have been shown to play a significant role in neuroprotection. The association between $\mathrm{HDL}_{-}$levels and cognition could be attributed to the higher cardiovascular risk associated with lower $\mathrm{HDL}$ [18].

The brain contains two main polyunsaturated fatty acids (PUFA): arachidonic acid (AA) and docosahexaenoic acid (DHA). Deficient diets in omega 3 PUFA lead to reduced DHA in the brain and increased turnover of AA to eicosanoids, an effect which is overcome by restoring the omega 3 PUFA to the diet. In neural trauma and neurodegenerative diseases, there is a dramatic rise in the levels of AA-derived eicosanoids. In contrast, DHA-derived compounds can prevent neuroinflammation [19]. In our study, the diabetics with mild cognitive impairement had a lower daily intake of choline and eicosapentaenoic acid. Using MoCA evaluation, mild cognitive impairement was associated with choline and essential fatty acids intake. This observational finding is biased by the design of the study. Clinical trials, with the registration of the FFA intake from multiple days should be realized to confirm this hypothesis [20-29].

\section{Conclusions}

In our study, abnormal scores of cognitive dysfunction were found in type 2 diabetics. They were correlated with glycemic control, high density cholesterol and free fatty acids intake. Underlying the implications of FFA intake in the development of dementia, in type 2 diabetics, is important in disease prevention. The results of our study should be confirmed by prospective studies or clinical trials.

\section{References}

1.CUKIERMAN-YAFFE T. Diabetes, dysglycemia and cognitive dysfunction. Diabetes Metab Res Rev. 2014 Jul;30(5):341-345. doi: 10.1002/dmrr.2507.

2.WALLIN A, ROMAN GC, ESIRI M, KETTUNEN P, SVENSSON J, PARASKEVAS GP, KAPAKI E. Update on Vascular Cognitive Impairment Associated with Subcortical Small-Vessel Disease. J Alzheimers Dis. 2018;62(3):1417-1441. doi: 10.3233/J AD-170803.

3.AURSULESEI, V., BULUGHIANA, S., STOICA, B.A., ANISIE, E., Circulating Chemerin, Oxidative Stress, Inflammation and Insulin Resistance in Morbid Obesity., Rev.Chim.(Bucharest), 68, no.5, 2017, p.1014-1018. 
4.DATCU MD, DATCU G, FERME a ANU I, AURSULESEI V. Pheochromocytoma Late Diagnosis After Subarachnoid Haemorrhage.Acta Endo(Buc) 2009;5(2):265-274

5.MC CRIMMON RJ, RYAN CM, FRIER BM. Diabetes and cognitive dysfunction. Lancet. 2012; 16; 379(9833) :2291-2299. doi: 10.1016/S01406736(12)60360-2.

6.AURSULESEI V., VASINCU D., TIMOFTE D., ET AL. New mechanisms of vesicles migration. Gen. Physiol. Biophys. 2016;35:287-298.

7.VAN BLOEMENDAAL L., IJ ZERMAN R. G., TEN KULVE J. S., BARKHOF F., DIAMANT M., VELTMAN D. J., ET AL. Alterations in white matter volume and integrity in obesity and type 2 diabetes. Metab. Brain Dis. 2016, 31, 621-629. 10.1007/s11011-016-9792-3.

8.XIA W., WANG S., RAO H., SPAETH A. M., WANG P., YANG Y., ET AL. Disrupted resting-state attentional networks in T2DM patients. Sci. Rep. 2015, 5:11148. 10.1038/srep11148

9.NASREDDINE ZS, PHILLIPS NA, BÉDIRIAN V, CHARBONNEAU S, WHITEHEAD V, COLLIN I, CUMMINGSJL, CHERTKOW H. The Montreal Cognitive Assessment, MoCA: a brief screening tool for mild cognitive impairment. J Am Geriatr Soc. 2005, 53 (4): 695-699. doi:10.1111/j.15325415.2005.53221.

10.GUO Q.; CAO X.; ZHOU Y.; ZHAO Q.; DING D.; HONG Z. Application study of quick cognitive screening test in identifying mild cognitive impairment. Neuroscience Bulletin. 2005, 26 (1): 47-54. doi:10.1007/ s12264-010-0816-4.

11.OTT A, STOLK RP, VAN HARSKAMP F, POLS HOFMAN A, BRETELER $M$. Diabetes mellitus and the risk of dementia: The Rotterdam Study. Neurology. 1999;59(9):1937-1942.

12.HARDIGAN T, WARD R, ERGUL A. Cerebrovascular Complications of Diabetes: Focus on Cognitive Dysfunction. Clin Sci (Lond). 2016; 130(20): 1807-1822. doi:10.1042/CS20160397.

13.YAFFE K, BLACKWELL T, WHITMER RA, KRUEGER K, BARRETT CONNOR E. Glycosylated hemoglobin level and development of mild cognitive impairment or dementia in older women. J Nutr Health Aging. 2006;10(4):293-295.

14.DING J, STRACHAN MWJ, REYNOLDS RM, FRIER BM, DEARY IJ, FOWKES FGR, ET AL. Diabetic Retinopathy and Cognitive Decline in Older The Edinburgh Type 2 Diabetes Study. 2010;59:2883-2889.

15.SUN Y, LEE J, MA RC, KWOK T Serum high-density lipoprotein cholesterol is a protective predictor of executive function in older patients with diabetes mellitus. J Diabetes Investig. 2018, doi: 10.1111/ jdi.12865. [Epub ahead of print].

16.BALAZS Z, PANZENBOECK U, HAMMER A. ET AL. Uptake and transport of high-density lipoprotein (HDL) and HDL-associated alphatocopherol by an in vitro blood-brain barrier model. J Neurochem. 2004;89(4):939-950.
17.KOLDAMOVA RP, LEFTEROV IM, LEFTEROVA MI ET AL. Apolipoprotein A-I directly interacts with amyloid precursor protein and inhibits A beta aggregation and toxicity. Biochemistry. 2001 Mar 27;40(12):3553-3560.

18.KHERA AV, CUCHEL M, DE LA LLERA-MOYA M. ET AL. Cholesterol efflux capacity, high-density lipoprotein function, and atherosclerosis. N Engl J Med. 2011; 364(2):127-135

19.TASSONI D, KAUR G, WEISINGER RS, SINCLAIR AJ. The role of eicosanoids in the brain. Asia Pac J Clin Nutr. 2008;17 Suppl 1:220-228. 20.MATEI,M.N., EARAR, K., TRINCA,L.C., Degradation characteristics of poly-tetrafluorethylene coatings on stainless steel orthodontic wires immersed in tuna fish derived products, Rev.Chim.(Bucharest), 67, no.4, 2016, p.800-807

21.MARECI, D., EARAR, K., ZETU, I., et al., Comparative electrochemical behaviour of uncoated and coated Ni-Ti for dental orthodontic wires, Mat. Plast., 52, no.2, 2015, p.150-153

22. ANTOHE, M.E., AGOP FORNA, D., DASCALU, C.G., Implications of digital image processing in the paraclinical assessment of the partially edentated patient, Rev.Chim. (Bucharest), 69, no.2, 2018, p.521-524 23. POPESCU, E., AGOP FORNA, D., EARAR, K., FORNA, N.C., Bone substitutes used in guided bone regeneration technique review, Mat. Plast., 54, no.2, 2017, p. 390-392

24.CHECHERITA, L., BELDIMAN, M.A., STAMATIN ,O., et al. Aspects on structure of materials used for different types of occlusal splints., Rev.Chim.(Bucharest), 64, no.8, 2013,p.864-867

25.GRADINARU, I., IGNAT, L., DASCALU, C.G., SOROAGA, L.V., ANTOHE, $M . E .$, Studies regarding the architectural design of various composites and nanofibres used in dental medicine, Rev.Chim.(Bucharest), 69, no.2, 2018, p.328-331

26.BUHACEANU, R., LUNGU, N.C., FORNA, N.C., et all, Anew Class of Mesoionic4-(1,3-Dithiol-2-ylium)phenolates, Rev. Chim.(Bucharest), 64, no.8, 2013, p.803-807

27.BUHACEANU, R., LUNGU, N.C., FORNA, N.C., et all, The Influence of Bromine Substituent on Optical Properties of Some 1,3-Dithiolium Derivatives, Rev.Chim.(Bucharest), 64, no.9, 2013, p 960-964

28.COSTACHE,I.I., UNGUREANU, M.C., ILIESCU,D., ET AL., Electrocardiographic changes in the most frequent endocrine disorders associated with cardiovascular diseases, review of the literature, Medical-surgical journal,119(1), 2015, pg. 18-22 29.PETRIS ,A., CIMPOESU ,D., COSTACHE,I ET. AL.Revista romana de Bioetica,992), ,2011,pg,99-108

$\overline{\text { Manuscript received: } 22.08 .2018}$ 